\title{
POTRZEBA SZKOLEŃ SPECJALISTYCZNYCH DEDYKOWANYCH PRACOWNIKOM SEUŻBY ZDROWIA
}

\begin{abstract}
Streszczenie: W rozdziale dokonano analizy potrzeby szkoleń specjalistycznych wśród pracowników służby zdrowia - lekarzy, pielęgniarek, personelu pomocniczego. Pracownicy służby zdrowia oprócz umiejętności i klasyfikacji wynikających $\mathrm{z}$ uprawianego zawodu powinni posiadać umiejętności, które podnoszą komfort pracy, zwłaszcza jeśli chodzi o kontakt z pacjentem. Bardzo często pracownicy służby zdrowia nie posiadają tzw. umiejętności „miękkich”, które ułatwiają pracę w stresujących warunkach między samymi pracownikami, jak i pracownikami i pacjentami. Naczelna Izba Lekarska posiada w swoim pakiecie edukacyjnym różne rodzaje szkoleń. Jednak brakuje tych, które pomagałyby pracownikom służby zdrowia identyfikować zagrożenia $\mathrm{z}$ grupy psychospołecznych zagrożeń zawodowych i wskazywać jak sobie $\mathrm{z}$ nimi radzić. W rozdziale przedstawiono wyniki ankiety przeprowadzonej wśród pracowników śląskich placówek służby zdrowia, która dotyczyła m.in. opinii respondentów na temat potrzeb szkoleń dodatkowych i specjalistycznych dla pracowników służby zdrowia.
\end{abstract}

Słowa kluczowe: szkolenia specjalistyczne, służba zdrowia, umiejętności "miękkie", zagrożenia psychospołeczne

\section{Wprowadzenie}

Pracownicy służby zdrowia to bardzo duża i specyficzna grupa zawodowa. Umiejętności i kompetencje zawodowe wynikają przede wszystkim ze ściśle określonych studiów, specjalności i odbytych staży. Praca zawodowa jest konsekwencją nabytej wiedzy i umiejętności. Pracownicy służby zdrowia są narażeni na szereg zagrożeń powiązanych z czynnikami niebezpiecznymi (wypadkowymi), ale również uciążliwymi bądź szkodliwymi, do których z kolei zalicza się czynniki fizyczne, biologiczne, chemiczne oraz psychofizyczne [1].

W świetle danych Europejskiej Agencji Bezpieczeństwa i Zdrowia w Pracy ponad 10\% pracowników Unii Europejskiej zatrudnionych jest w sektorze służby zdrowia i opieki społecznej, a dość duży odsetek tych pracowników pracuje w szpitalach. Sektor ten należy do największego sektora zatrudniającego w Europie i obejmuje dużą grupę rożnych zawodów, m.in. lekarzy, pielęgniarki i tzw. pomocniczy personel medyczny. Jest to sektor sfeminizowany, gdyz $77 \%$ siły roboczej stanowią kobiety [2]. Ponadto w sektorze służby zdrowia częstość

\footnotetext{
${ }^{1}$ Dr n. med., Politechnika Częstochowska, jolanta.jasik-slezak@wz.pcz.pl, ORCID ID: 0000-0002-08763569
} 
wypadków przy pracy jest 34\% wyższa niż średnia dla całej Unii Europejskiej, a sam sektor znajduje się na drugim miejscu, zaraz po budownictwie, jeśli chodzi o częstość występowania chorób układu mięśniowo-szkieletowego związanych z pracą [3].

Za główne czynniki ryzyka w sektorze służby zdrowia Unii Europejskiej oraz wiązane $\mathrm{z}$ nimi problemy zdrowotne uznaje się przede wszystkim wspomniane już obciążenia układu mięśniowo-szkieletowego, wynikające $\mathrm{z}$ wadliwych postaw ciała przy wykonywaniu pracy oraz nieprawidłowego podnoszenia i przenoszenia ciężarów. Ponadto Europejska Agencja Bezpieczeństwa i Zdrowia w Pracy (EU-OSHA) zwraca uwagę na czynniki biologiczne - mikroorganizmy, zanieczyszczona krew, wirusy np. HIV czy zapalenia wątroby typu $\mathrm{B}$, jak również wypadki przy pracy, które maja postać mikrourazów, skaleczeń, zakłuć itp. Również czynniki chemiczne obecne w środowisku pracy służby zdrowia stanowią grupę czynników ryzyka wskazywanych za główne [4]. Należą do nich zwłaszcza środki dezynfekcyjne, gazy znieczulające, antybiotyki. Związki te mogą być szkodliwe dla skóry lub układu oddechowego, mogą również być rakotwórcze. Do ważniejszych czynników ryzyka w służbie zdrowia zalicza się również zagrożenia pracą zmianową, zwłaszcza nocną, które niosą za sobą wiele niepożądanych zjawisk i zachowań - przemęczenie, obniżenie stopnia sprawności fizycznej i umysłowej, pomyłki wynikające $\mathrm{z}$ obniżonej uwagi i koncentracji itp.

Coraz częściej w krajach Unii Europejskiej zaczyna się zwracać uwagę na zagrożenia, które trudno zidentyfikować. Są to zagrożenia należące do grupy psychospołecznych, m.in. agresja pacjentów oraz członków ich rodzin, która nie rzadko ma postać przemocy fizycznej i psychicznej wobec pracownika służby zdrowia [5]. Badania dotyczące warunków pracy ale i zagrożeń zawodowych w służbie zdrowia, powadzone przez EU-OSHA są rzetelne i dobrze dokumentowane. W Polsce wciąż brakuje rzetelnych badań dotyczących warunków pracy oraz identyfikacji zagrożeń w służbie zdrowia. Brakuje również systemowego kształcenia pracowników służby zdrowia w obszarach, które odpowiadają za jakość kontaktu z pacjentem. Chodzi przede wszystkim o szkolenia, które uzupełniałyby wiedzę i kompetencje, ale przede wszystkim umiejętności praktyczne związane $\mathrm{z}$ identyfikacją zagrożeń „nowych i pojawiających się” zwłaszcza z grupy zagrożeń psychospołecznych. Wciąż słyszy się o roszczeniowych pacjentach, agresywnych członkach rodzin pacjentów ale i znerwicowanych, traktujących bezosobowo pacjentów pracowników służby zdrowia - lekarzy, pielęgniarki, czy też medyczny personel pomocniczy[1]. 


\section{Szkolenia rekomendowane przez Naczelną Izbę Lekarską}

Po wielkiej emigracji polskich lekarzy po 2004 roku do krajów Unii Europejskiej, zaczęto coraz bardziej dostrzegać wśród większości pracowników służby zdrowia brak umiejętności radzenia sobie m.in. ze stresem w miejscu pracy[6]. Takie pojęcia jak zarządzanie stresem zawodowym, radzenie sobie $\mathrm{z}$ agresją pacjentów, efektywna komunikacja między personalna to były pojęcia nader egzotyczne dla większości personelu medycznego. W Polsce od lat pracowało się zawsze zbyt dużo i zbyt szybko, a stres zawodowy był tłumiony w różny sposób. Wielu specjalistów podnosiło $\mathrm{w}$ tym czasie próby zidentyfikowania przyczyn wysokiego poziomu stresu zawodowego wśród pracowników służby zdrowia i jego efektów w postaci dolegliwości zdrowotnych oraz patologicznych zjawisk w postaci nadużywania leków, nikotyny czy alkoholu.

W 2008 roku Naczelna Rada Lekarska powołała do życia Ośrodek Doskonalenia Zawodowego Lekarzy i Lekarzy Dentystów Naczelnej Izby Lekarskiej. Ośrodek od tego czasu organizuje szkolenia dla lekarzy i lekarzy dentystów w zakresie umiejętności społecznych, zwanych także kompetencjami miękkimi. Zalicza się do nich komunikację między ludźmi, umiejętność współpracy, motywowanie, radzenie sobie ze stresem i wypaleniem zawodowym, a także rozwiązywanie konfliktów i budowanie prawidłowych relacji interpersonalnych. Kształcenie w zakresie kompetencji miękkich rozwija i wzmacnia umiejętność budowania relacji lekarz-pacjent, lekarz-lekarz oraz lekarz-przedstawiciele innych profesji. Brak umiejętności w tym zakresie może być przyczyną problemów osobistych i trudności w pracy. Powszechnie uznawany jest też za najczęstszy powód roszczeń i odpowiedzialności zawodowej. Potrzebę zdobywania i doskonalenia umiejętności komunikacyjnych podkreślają niemal wszyscy lekarze, którzy stykają się z tą problematyką. Ośrodek Doskonalenia Zawodowego Lekarzy i Lekarzy Dentystów Naczelnej Izby Lekarskiej, poza prowadzeniem bezpłatnych szkoleń dla lekarzy, ma także zadanie zbierania i opiniowania wniosków o dotacje do doskonalenia zawodowego organizowanego przez okręgowe izby lekarskie [7].

$\mathrm{Na}$ stronie szkoleń dostępnych dla pracowników służby zdrowia widnieją następujące tematy szkoleń specjalistycznych i problemowych:

- „Poszukiwanie rozwiązań rozwojowych w podmiotach leczniczych”

Podstawowym celem takiego szkolenia jest zwiększenie efektywności menedżerskiej poprzez dostarczenie jego uczestnikom najnowszej wiedzy oraz pogłębienie kluczowych kompetencji niezbędnych do nowoczesnego zarządzania podmiotem leczniczym w warunkach silnej konkurencji na rynku usług zdrowotnych. Szkolenie oferuje zróżnicowane jego formy w postaci interaktywnych warsztatów, wykładów, dyskusji, przeglądu najlepszych praktyk oraz pracy grupowej w oparciu 
o case studies pozwalają uporządkować i pogłębić umiejętności menedżerskie w następujących obszarach: komunikacji z kluczowymi interesariuszami, relacji $\mathrm{z}$ pracownikami, technik motywacyjnych i negocjacyjnych, a także $\mathrm{w}$ procesie zarządzania zmianą wewnątrz i na zewnątrz organizacji.

Istotnym punktem warsztatów będzie pogłębiony przegląd najlepszych praktyk zarządczych i rozwojowych na rynku usług medycznych a ich dopełnieniem będzie próba pokazania, jak tworzyć zoptymalizowane rozwiązania strategiczne w różnych typach podmiotów medycznych. Podczas warsztatów uczestnicy będą mieli możliwość pracy grupowej nad specjalnie przygotowanymi case studies, do których rozwiązania będzie niezbędna wiedza i umiejętności zdobyte w trakcie szkolenia. Dodatkową wartością takiego szkolenia jest okazja do wymiany doświadczeń profesjonalnych i dyskusji nad wdrażaniem skutecznych rozwiązań z zakresie organizacji i zarządzania jednostkami, którymi kierują lub w których pracują uczestnicy warsztatów [8].

- „Umiejętności kierowania zespołem”

Szkolenie takie ma charakter 1-dniowego interaktywnego warsztatu, nakierowanego na trening konkretnych umiejętności wykorzystywanych w zarządzaniu ludźmi i zespołami. Metodologia szkolenia jest oparta na metodach aktywnego uczenia dorosłych: trening umiejętności, studium przypadku, symulacja sytuacji zawodowych, prezentacje, gry, wykłady interaktywne, praca z kamerą video, dyskusje grupowe i burze mózgów, praca w podgrupach zadaniowych. Celem szkolenia jest dostarczenie wiedzy i umiejętności związanych $\mathrm{z}$ efektywnym kierowaniem zespołem i motywowaniem go do osiągania pożądanych efektów w pracy [8].

- „Rozwiązywanie konfliktów w relacji z pacjentem oraz reagowanie na obiekcje i zarzuty z jego strony"

Szkolenie takie ma na celu dostarczenie wiedzy i umiejętności pomocnych w konstruktywnym rozwiązywaniu konfliktów w relacji z pacjentem oraz reakcji na zgłaszane obiekcje i zarzuty. Szkolenie prowadzone jest w formie warsztatów. Odbiorcą takiego szkolenia może być każdy pracownik placówki świadczącej usługi medyczne [8].

- „Motywowanie pracowników i wzmacnianie relacji”

Jest to szkolenie, które ma na celu dostarczenie wiedzy i umiejętności związanych z efektywnym motywowaniem pracowników do osiągania pożądanych efektów w pracy oraz budowaniu relacji sprzyjających wzajemnej współpracy [8]. 
- „Zarządzanie sobą w czasie”

Celem niniejszego szkolenia z kolei jest dostarczenie wiedzy i umiejętności planowania oraz organizacji pracy i zadań oraz praca nad postawą związaną $\mathrm{z}$ własnymi schematami i rutyną w planowaniu pracy i zarządzaniu czasem [8].

- „Agresywny pacjent - aspekty prawne”

Agresja ze strony pacjentów stanowi coraz poważniejszy problem w pracy lekarzy. Celem takiego szkolenia jest przekazanie wiedzy, jak przy pomocy obowiązującego prawa radzić sobie z agresywnym pacjentem jak również wyjaśnienie wątpliwości, czy lekarz może odmówić udzielenia świadczenia zdrowotnego agresywnemu pacjentowi, w jakich sytuacjach przysługuje lekarzowi ochrona prawna oraz jaki ma ona zakres [8].

- „Jak radzić sobie w sytuacjach trudnych?”

Trudne sytuacje mogą pojawić się w praktyce każdego lekarza: podczas rozmowy z pacjentem, współpracownikiem, pracodawcą. Umiejętność radzenia sobie w trudnych sytuacjach jest bardzo przydatna, gdy lekarzowi zależy na zdobyciu zaufania rozmówcy, przekonaniu pacjenta do określonych badań diagnostycznych, zalecanej terapii. Jest niezbędna dla efektywnej pracy lekarza, bez ponoszenia niepotrzebnych kosztów emocjonalnych [8].

Szkolenia rekomendowane przez NIL dotyczą różnych tematów. Można jeszcze wymienić szkolenia takie jak [ 8]:

- Dziecko i Rodzic w gabinecie lekarskim i stomatologicznym,

- Dokumentacja medyczna, e-dokumentacja,

- Warsztaty dla lekarzy i lekarzy dentystów w zakresie budowania relacji interpersonalnych ze współpracownikami oraz komunikacji marketingowej placówek medycznych z otoczeniem rynkowym,

- Kontrola zarządcza i audyt wewnętrzny w sektorze ochrony zdrowia oraz korupcja w ochronie zdrowia i metody jej zapobiegania,

- Komunikacja i relacje lekarza z pacjentem w podeszłym wieku,

- Bezsenność - jak zasnąć, spać i wypocząć? Psychologiczne metody radzenia sobie z bezsennością,

- Controlling i zarządzanie ryzykiem w działalności leczniczej,

- Kiedy rodzic nie chce szczepić - warsztaty skutecznej komunikacji na temat szczepień,

- Specyfika pracy lekarza z chorym umierającym i jego bliskim,

- Radzenie sobie ze stresem i przeciwdziałanie wypaleniu zawodowemu,

- Warsztaty skutecznych negocjacji, 
- Analiza transakcyjna jako metoda reagowania na zachowania agresywne,

- Mobbing - przemoc psychiczna w miejscu pracy - jak rozpoznawać, zapobiegać, postępować,

- Ochrona radiologiczna pacjentów dla lekarzy dentystów wykonujących medyczne procedury radiologiczne - kurs tylko dla lekarzy dentystów,

- Asertywna komunikacja lekarzy,

- Rozwiązywanie konfliktów interpersonalnych w pracy lekarza,

- Jak motywować pacjenta do skorzystania z zalecanego przez lekarza dentystę planu leczenia? - sztuka negocjacji partnerskich,

- Angażowanie pacjenta w leczenie i modyfikację stylu życia.

Oferta szkoleniowa proponowana przez NIL jest dość bogata. Zadać sobie należy więc pytanie dlaczego nadal problemy, które poruszane są na szkoleniach stanowią przyczynę wszelkich negatywnych zdarzeń i zjawisk w placówkach służby zdrowia? Otóż okazuje się, że w szkoleniach, które w większości są bezpłatne bierze udział garstka pracowników służby zdrowia. Pracownicy wskazują brak czasu jako główną przyczynę braku uczestnictwa w szkoleniach specjalistycznych czy dodatkowych. Ponadto - paradoksalnie - duża grupa deklaruje chęć udziału w szkoleniach podnoszących ich kompetencje „miękkie”. W niniejszej pracy przeprowadzono badania ankietowe w kilkunastu placówkach służby zdrowia województwa śląskiego.

\section{Badania w placówkach służby zdrowia województwa śląskiego}

Badanie ankietowe przeprowadzono w 12 placówkach służby zdrowia w województwie śląskim. W badaniu łącznie wzięło udział 76 lekarzy (45 kobiet, 31 mężczyzn), 64 pielęgniarki i 36 pomocniczego personelu medycznego (28 kobiet, 8 mężczyzn), czyli 176 osób. W kwestionariuszu ankietowym respondenci odpowiadali na pytania dotyczące potrzeby uczestniczenia personelu medycznego w dodatkowych szkoleniach specjalistycznych. Prawie $74 \%$ badanych respondentów deklarowało silną potrzebę uczestniczenia w takich szkoleniach. Wyniki prezentuje tabela 1.

Tabela 1. Deklarowanie uczestniczenia w specjalistycznych szkoleniach w opinii respondentów $w$ ujęciu procentowym

\begin{tabular}{|l|l|l|l|l|l|}
\hline $\begin{array}{l}\text { Bardzo } \\
\text { chętnie }\end{array}$ & Chętnie & Możliwe & $\begin{array}{l}\text { Niezbyt } \\
\text { chętnie }\end{array}$ & Niechętnie & $\begin{array}{l}\text { Nie mam } \\
\text { potrzeby }\end{array}$ \\
\hline $74 \%$ & $7 \%$ & $2 \%$ & $9 \%$ & $3 \%$ & $5 \%$ \\
\hline
\end{tabular}

Źródto: Opracowanie własne 
Respondenci wskazali również, które z obszarów szkoleń interesowałyby ich najbardziej. Respondenci mogli wybrać więcej niż jeden rodzaj szkoleń. W tabeli numer 2 przedstawiono wyniki. Najczęściej respondenci deklarują potrzebę szkoleń $\mathrm{z}$ obszaru dotyczącego radzenia sobie $\mathrm{z}$ agresywnym pacjentem $(58 \%)$, w dalszej kolejności wskazują na potrzebę szkolenia z obszarów dotyczących radzenia sobie z we stresem i wypaleniem zawodowym (34\%).

Tabela 2. Deklarowanie obszarów szkoleń najbardziej potrzebnych $w$ opinii respondentów w ије̨сіи \%

\begin{tabular}{|l|l|l|l|l|}
\hline $\begin{array}{l}\text { Jak radzić } \\
\text { sobie z } \\
\text { agresywnym } \\
\text { pacjentem? }\end{array}$ & $\begin{array}{l}\text { Jak radzić } \\
\text { sobie ze } \\
\text { stresem i } \\
\text { wypaleniem } \\
\text { zawodowym? }\end{array}$ & $\begin{array}{l}\text { Równowaga } \\
\text { praca-życie } \\
\text { prywatne }\end{array}$ & $\begin{array}{l}\text { Jak radzić } \\
\text { sobie z } \\
\text { roszczeniowym } \\
\text { pacjentem - } \\
\text { aspekty prawne }\end{array}$ & $\begin{array}{l}\text { Zagrożenia } \\
\text { w pracy } \\
\text { z pacjentem } \\
\text { trudnym pod } \\
\text { względem } \\
\text { neurologicznym }\end{array}$ \\
\hline $58 \%$ & $34 \%$ & $10 \%$ & $12 \%$ & $9 \%$ \\
\hline
\end{tabular}

Źródto: Opracowanie własne

W dalszej kolejności respondenci odpowiedzieli na pytanie dotyczące czynników, które ograniczają bądź eliminują ich uczestnictwo w szkoleniach. Respondenci mogli wskazać więcej niż jedną odpowiedź. Najczęstszymi przyczynami wskazywanymi przez respondentów był brak czasu (67\%), brak siły fizycznej i psychicznej, zwłaszcza po nocnych dyżurach (23\%), kwestie rodzinne (12\%), kwestie zdrowotne (9\%). W tabeli numer 3 przedstawiono wyniki tych badań.

Tabela 3. Czynniki uniemożliwiające uczestniczenie w szkoleniach w opinii respondentów

\begin{tabular}{|l|l|l|l|l|}
\hline Brak czasu & $\begin{array}{l}\text { Brak siły } \\
\text { spowodowany } \\
\text { np. dyżurami } \\
\text { nocnymi }\end{array}$ & $\begin{array}{l}\text { Kwestie } \\
\text { rodzinne }\end{array}$ & $\begin{array}{l}\text { Kwestie } \\
\text { zdrowotne }\end{array}$ & $\begin{array}{l}\text { Niechęć, } \\
\text { ogólnie } \\
\text { negatywne } \\
\text { nastawienie do } \\
\text { pozyskiwania } \\
\text { dodatkowej } \\
\text { wiedzy }\end{array}$ \\
\hline $58 \%$ & $34 \%$ & $10 \%$ & $12 \%$ & $9 \%$ \\
\hline
\end{tabular}

Źródto: Opracowanie własne 
Kwestie zdrowotne jako czynnik uniemożliwiający uczestniczenie w szkoleniach zadeklarowało $12 \%$ respondentów. Z kolei $9 \%$ spośród wszystkich ankietowanych za powód nieuczestniczenia w szkoleniach podało ogólną niechęć do uczestniczenia w szkoleniach dodatkowych.

\section{Podsumowanie}

Praca w służbie zdrowia jest bardzo wymagająca. Pracownik służby zdrowia lekarz, pielęgniarka, medyczny pracownik pomocniczy - ma codzienny kontakt z różnymi zagrożeniami. Począwszy od zagrożeń biologicznych, chemicznych przez zagrożenia o charakterze wypadkowym, na zagrożeniach psychospołecznych skończywszy. Oprócz przygotowania zawodowego pracownik służby zdrowia powinien posiadać wiedzę, która pomogłaby mu w codziennym podejmowaniu decyzji w kwestiach, które wychodzą poza ramy tego, do czego przygotowały go studia bądź szkoła zawodowa. Są to przede wszystkim umiejętności dotyczące pozytywnego kształtowania relacji z innymi pracownikami jak i pacjentami.

Naczelna Izba lekarska coraz częściej proponuje pracownikom służby zdrowia bezpłatne szkolenia w różnych obszarach. Są to obszary dotyczące przede wszystkim zagrożeń psychospołecznych, m.in. agresja pacjentów i ich rodzin, wypalenie zawodowe czy stres zawodowy. Wyniki przeprowadzonych badań wykazują, iż istnieje ogromna potrzeba wśród pracowników służby zdrowia na uczestniczenie w takich szkoleniach. Niestety pojawia się również informacja, że większość z nich nie ma czasu na odbycie takich szkoleń. Duże obciążenie czasem pracy w służbie zdrowia to kolejny temat, w którym należy przede wszystkim dokonać kontroli zgodności przepracowanych godzin do przepisów związanych z czasem pracy pracowników służby zdrowia. Brak systemowego podejścia do tematu szkoleń, a przede wszystkim brak obligatoryjności takich szkoleń powoduje, że chętni pracownicy $\mathrm{w}$ efekcie sięgają po nie rzadko.

\section{Literatura}

[1] Niciejewska M., Marjański J.: Identyfikacja zagrożeń zawodowych w pracy lekarza pierwszego kontaktu ze szczególnym uwzględnieniem zagrożeń „nowych i pojawiajacych się”. Zeszyty Naukowe Politechniki Łódzkiej (w druku).

[2] Europejska Agencja Bezpieczeństwa i Zdrowia w Pracy, Dobre praktyki na rzecz poprawy BHP w sektorze służby zdrowia, FACTS, https://osha.europa.eu/p1/tools-andpublications/publications/factsheets/29 z dnia 10.01.2019. 
[3] Niciejewska M., Klimecka-Tatar D.: Evaluation of Static Load in Dentists' Work by Means of OWAS Method. Czasopismo Techniczne. Mechanika, 2016 3M/113, s. 125130.

[4] Gańczak M., Topczewska K.: Ryzyko ekspozycji zawodowej na patogeny krwiopochodne u ratowników medycznych. Medycyna Pracy 2018, 69(6), s. 685-694.

[5] Mościcka A.: Opieka profilaktyczna dotyczaca psychospołecznych zagrożeń w miejscu pracy. Medycyna Pracy 2010; 61 (1), s. 91-100.

[6] Irzyniec T., Konodyba-Szymański P., Szczerba H.: Identyfikacja zagrożeń ora ocena ryzyka zawodowego lekarzy medycyny (wyniki wstęne), JEcolHealth, 2010, vol. 14, Nr 6, s. 296. https://www.nil.org.pl/dzialalnosc/orodek-doskonalenia-zawodowego-lekarzyi-lekarzy-dentystow (odczyt 12.03.2019).

[7] https://www.nil.org.pl/dzialalnosc/orodek-doskonalenia-zawodowego-lekarzy-i-lekarzydentystow z dnia (odczyt 21.02.2019).

[8] https://www.nil.org.pl/dzialalnosc/orodek-doskonalenia-zawodowego-lekarzy-i-lekarzydentystow/szkolenia-prowadzone-przez-nil z dnia (odczyt 23.04.2019).

\title{
THE NEED FOR SPECIALIST TRAINING DEDICATED TO HEALTH SERVICE EMPLOYEES
}

\begin{abstract}
The chapter analyzes the need for specialist training among healthcare professionals - doctors, nurses, support staff. In addition to skills and classifications resulting from the profession, health professionals should have skills that improve the comfort of work, especially when it comes to contact with the patient. Very often, health care workers do not have so-called "soft" skills that facilitate working in stressful conditions between the employees themselves as well as employees and patients. The Chief Medical Chamber has in its educational package, various types of training. However, there are a lack of those that would help healthcare professionals identify risks from the group of psychosocial occupational hazards and indicate how to deal with them. The chapter presents the results of a survey conducted among employees of Silesian health care institutions, which concerned respondents' opinions on the needs of additional and specialist training for health professionals.
\end{abstract}

Key word: specialized training, health care, "soft" skills, psychosocial risks

Data przesłania publikacji do Redakcji: 07.03.2019

Data akceptacji publikacji przez Redakcję: 15.06.2019

DOI: 10.30657/qpi.2019.10.11 